\title{
Parental contribution in a cultivated stock for the spotted rose snapper Lutjanus guttatus (Steindachner, 1869) estimated by newly developed microsatellite markers
}

\author{
Ricardo Perez-Enriquez ${ }^{1}$, Janeth A. Valadez-Rodríguez ${ }^{2}$, Adriana Max-Aguilar ${ }^{1}$ \\ Silvie Dumas ${ }^{3} \&$ Noe Diaz-Viloria ${ }^{3}$ \\ ${ }^{1}$ Centro de Investigaciones Biológicas del Noroeste, La Paz, B.C.S., México \\ ${ }^{2}$ Instituto Tecnológico de La Paz, La Paz, B.C.S., México \\ ${ }^{3}$ Instituto Politécnico Nacional, Centro Interdisciplinario de Ciencias Marinas \\ La Paz, B.C.S., México \\ Corresponding author: Ricardo Perez-Enriquez (rperez@ cibnor.mx)
}

\begin{abstract}
The spotted rose snapper Lutjanus guttatus is a fishery relevant species from the eastern Pacific Ocean, with aquaculture potential. Species-specific genetic markers are needed for the genetic characterization of wild and cultivated populations to help management strategies. Eighteen hypervariable microsatellites were developed by Next Generation Sequencing and characterized in a wild population sample. Genetic diversity was high (observed heterozygosity $=0.88 \pm 0.050$; the number of alleles per locus $=13.4 \pm 1.3$ ) and few loci departed from the Hardy-Weinberg Equilibrium, leaving 14 loci potentially suitable for population genetic studies. A reduced panel of five loci was tested in a cultivated stock to determine the parentage of progeny (embryonated eggs; $n=413$ ), to estimate the temporal contribution of each parental broodstock. The above resulted in the successful assignment of $95.6 \%$ of the progeny to its parental couple, representing 17 out of the 24 possible families. Two of the four females produced most of those progeny (97.3\%). These females, which reproduced throughout the season, did not spawn on consecutive days. The contribution of males was evenly distributed during the season and occurred on successive days. Some microsatellites can be used in other lutjanids (L. peru, L. argentiventris, and Hoplopagrus guentherii).
\end{abstract}

Keywords: Lutjanus guttatus; population genetics; embryonic eggs; genetic markers; parentage assessment; reproductive performance

\section{INTRODUCTION}

The spotted rose snapper, Lutjanus guttatus (Steindachner, 1869), is a demersal marine finfish with a wide distribution range along the eastern Pacific Ocean from the Gulf of California in Mexico to Ecuador (Fischer et al., 1995). It is a valuable fishing resource in the region (Herrera-Ulloa et al., 2010; Sarabia-Méndez et al., 2010; Correa-Herrera \& Jiménez-Segura, 2013), with a high potential for aquaculture (Ibarra-Castro et al., 2013). Lutjanus guttatus is a batch spawner with asynchronous ovarian development during a long reproductive season comprising peak spawning periods in April, August and October
(Arellano-Martínez et al., 2001; Sarabia-Méndez et al., 2010). Little is known regarding the spawning contribution of females and males daily.

Microsatellite genetic markers are a necessary tool for the genetic characterization of wild populations that can be used, for example, to improve their management, in rehabilitation programs, and stock identification (Hallerman, 2003). They are also important in aquaculture as they can be used to determine female spawning frequency. Thus, the effective parental contribution [e.g., red sea bream Pagrus major (PerezEnriquez et al., 1999), California yellowtail Seriola lalandi (Smith et al., 2015), gilthead seabream Sparus aurata (García-Fernández et al., 2018)], which due

Corresponding editor: Fernando Vega 
the disproportion in male to female contributions, large family size variance and null female spawners in the broodstock can lead to the potential accumulation of inbreeding within the hatchery (Blonk et al., 2009; Domingos et al., 2014). Other markers, such as Single Nucleotide Polymorphisms (SNPs), have shown reliable results for parentage testing in aquaculture species [e.g., shrimp (Perez-Enriquez \& Max-Aguilar, 2016)]. However, for $L$. guttatus there is no previous genomic information available.

The present study aimed to obtain a set of microsatellite markers for future population genetic studies of $L$. guttatus and to test a reduced panel to estimate the temporal parental contribution in a cultivated stock of the species.

\section{MATERIALS AND METHODS}

\section{Biological material}

Fin clips of 10 Lutjanus guttatus individuals were collected in 2011 at the eastern coast of the Baja California Peninsula, Mexico, and preserved in 70\% ethanol. Genomic DNA was obtained (Aljanabi \& Martinez, 1997), and a DNA mix was sent to the Savannah River Ecology Laboratory, University of Georgia, U.S.A., for microsatellite screening by Next Generation Sequencing (Illumina library preparation and sequencing, bioinformatics analysis and primer design). A set of 48 primer pairs (tetra- and pentanecleotides) was tested in these 10 individuals. PCR was done in volumes of $11 \mu \mathrm{L}$ containing $1 \mu \mathrm{L}$ DNA as template (20 ng $\left.\mu \mathrm{L}^{-1}\right), 1 \times$ Taq Buffer, $1.5 \mathrm{mM} \mathrm{MgCl}_{2}$, $0.25 \mathrm{mM}$ dNTPs, $0.4 \mu \mathrm{M}$ of each forward and reverse primers (Macrogen, Korea), $0.025 \mathrm{U}_{\mu \mathrm{L}^{-1}} \mathrm{Taq}$ polymerase (Promega, UK), and Milli-Q water. PCR thermal conditions (C1000 thermal cycler, Bio-Rad) were: $94^{\circ} \mathrm{C}$ for $2 \mathrm{~min} ; 30$ cycles at $94^{\circ} \mathrm{C}$ for $45 \mathrm{~s}$, annealing temperature for $45 \mathrm{~s}$, and $72^{\circ} \mathrm{C}$ for $1 \mathrm{~min}$; then a final extension at $72^{\circ} \mathrm{C}$ for $10 \mathrm{~min}$. The annealing temperature for each primer was calculated using the formula $T_{a}=4(C+G)+2(A+T)-5$. The PCR products were separated on polyacrylamide gel electrophoresis $(5 \%, 7.5 \mathrm{M}$ urea; $1800 \mathrm{~V}, 50 \mathrm{~mA}$, and $50 \mathrm{~W})$. Fragments were visualized using Sybr-Gold within a $1 \%$ agarose matrix and scanned (FMBIOIII, Hitachi).

\section{Genetic markers selection}

A set of 18 microsatellite loci, showing reliable amplification patterns, was selected for characterization on the same 10 individuals, and their sequences (Macrogen) were deposited in GenBank (Table 1). PCR reactions were done in $20 \mu \mathrm{L}$ volumes with the use of an M13 primer (5'-TGTAAAACGACGGCCAGT) labeled with the fluorophores 6-FAM, VIC, NED or PET at $1.6 \mu \mathrm{M}$, reverse primers at $1.6 \mu \mathrm{M}$, and forward primers having an extension of the M13 sequence at the 5'-end at $0.4 \mu \mathrm{M}$ (Schuelke, 2000) (Table 1). The rest of the components were at the same concentrations as above. The amplification conditions were the same as above, but the final extension was set with eight additional cycles of $94^{\circ} \mathrm{C}$ for $30 \mathrm{~s}, \mathrm{M} 13$-annealing at $53^{\circ} \mathrm{C}$ for $45 \mathrm{~s}$, and $72^{\circ} \mathrm{C}$ for $45 \mathrm{~s}$. Two $\mu \mathrm{L}$ of PCR products were added with $0.25 \mu \mathrm{L}$ of LIZ500 Size Standard (Applied Biosystems) and $9.75 \mu \mathrm{L}$ de HiDiformamide, placed in a 96-well microplate and put into the ABI 3130 automated DNA sequencer. The genotypes were obtained using the software Gene Mapper version 4.0 (Applied Biosystems).

Allele frequencies per locus were calculated with the program Arlequin version 3.5 (Excoffier \& Lischer, 2010), and used to estimate genetic diversity parameters [number of alleles per locus; observed (Ho) and expected (He) heterozygosities] and Hardy-Weinberg Equilibrium (HWE) (Exact test using a Markov chain: 50,000 dememorizations, 100,000 steps). The potential presence of null alleles, stuttering, or allele drop-out was assessed with the program Micro-Checker (VanOosterhout et al., 2004).

Cross-amplification of microsatellites was tested in three lutjanid species: red snapper Lutjanus peru (Nichols \& Murphy, 1922) ( $\mathrm{n}=5$ ), yellow snapper Lutjanus argentiventris (Peters, 1869) $(\mathrm{n}=4)$, and greenbar snapper Hoplopagrus guentherii (Gill, 1862) $(\mathrm{n}=1)$, all collected from the Gulf of California.

\section{Broodstock management}

The 10 individuals of $L$. guttatus described in the previous section (six males, four females) were kept in a maturation tank equipped with an external spawn collector, at the Centro Interdisciplinario de Ciencias Marinas-IPN, México. They were fed daily at satiation with sardines and squid. During the reproductive season of 2011 (June-October), spontaneous spawning was obtained. For each collected spawn, viable embryonated eggs were separated from dead eggs by buoyancy. A fraction of those was collected and preserved in $1.5 \mathrm{~mL}$ microcentrifugation tubes with $70 \%$ ethanol. From a total of 36 spawns, the embryonated eggs from 14 spawning events were sampled for DNA analysis (12, 13, 14 July; 4, 14, 22 August; 8, 9, 10 September; 14, 15, 16, 20, 21 October).

The embryonated eggs were individually separated using a microscope (Olympus CX31), and only those from the late gastrula developmental stage were selected, as earlier stages failed to amplify PCR products adequately. Remnants of ethanol were evapo- 


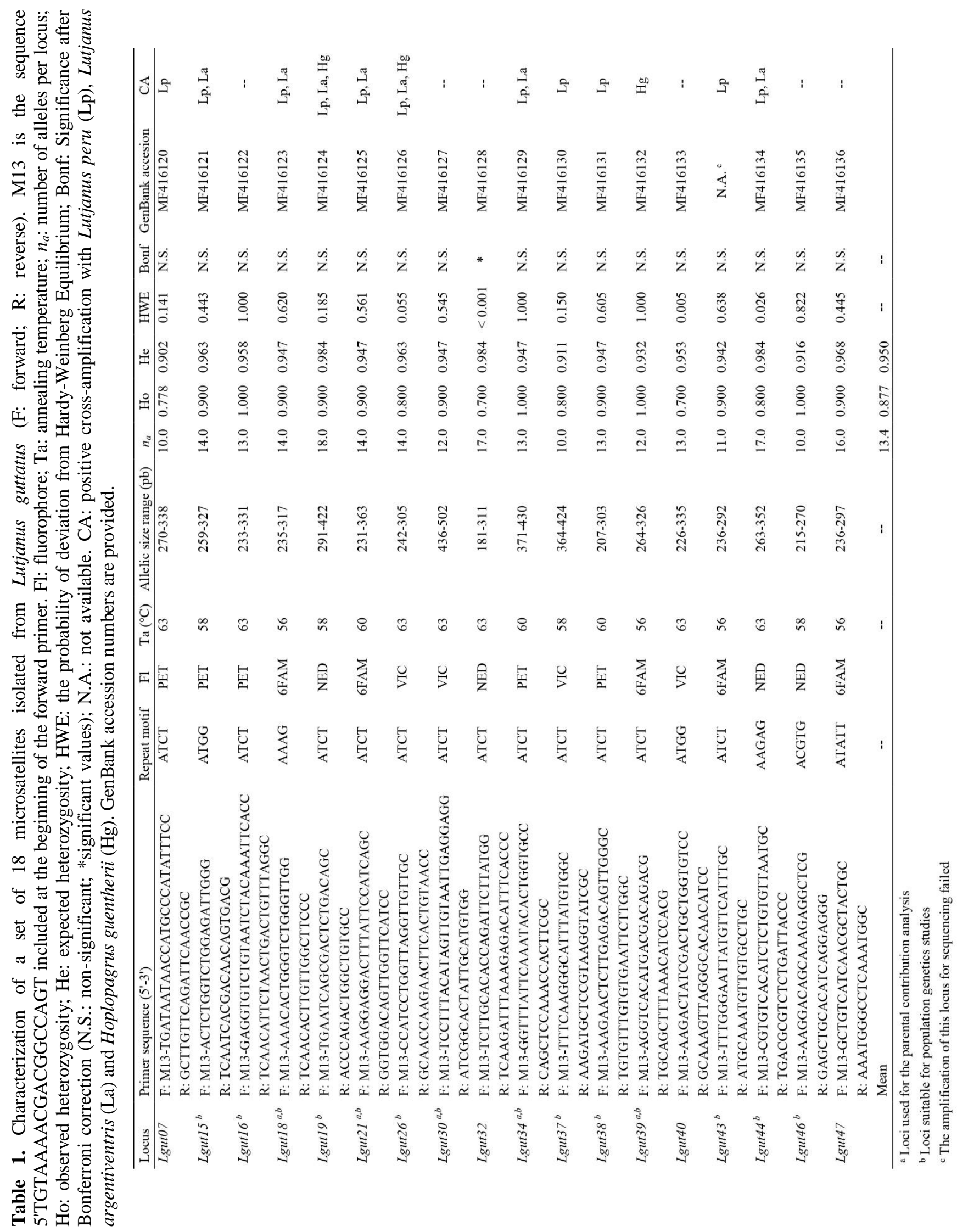


rated, and embryonated eggs were put into individual tubes with $18 \mu \mathrm{L}$ of MilliQ water. They were preserved at $-20^{\circ} \mathrm{C}$. For DNA release, embryonated eggs were unfrozen, smashed with a plastic pestle and centrifuged at $1,533 \mathrm{~g}$ for $1 \mathrm{~min}$. The supernatant was used as a DNA template. A total of 32 embryonated eggs from each of the 14 spawning events were used for genotyping.

\section{Parentage testing}

Based on their polymorphism, allelic range, electropherogram peak quality and the possibility of multiplexing, five loci were selected for genotyping (Table 1). The forward primer (without the M13 extension) from the microsatellite was labeled with a fluorescent label at 5' (Thermo Fisher Scientific) (6FAM-Lgut18, PET-Lgut21, 6FAM-Lgut30, NEDLgut34 and VIC-Lgut39). For adults, PCR multiplex reactions were conducted in $21 \mu \mathrm{L}$ volumes containing $1 \mu \mathrm{L}$ DNA $\left(20 \mathrm{ng} \mu \mathrm{L}^{-1}\right), 1 \times$ Taq buffer, $1.5 \mathrm{mM} \mathrm{MgCl}_{2}$, $0.35 \mathrm{mM}$ dNTPs, $0.3 \mu \mathrm{M}$ of each primer and $0.07 \mathrm{U}_{\mu} \mathrm{L}^{-1}$ Taq polymerase. For embryonated eggs, PCR reactions were done using the same quantities but in a volume of $23 \mu \mathrm{L}$ with $3 \mu \mathrm{L}$ of DNA. PCR thermal conditions were as follows: $94^{\circ} \mathrm{C}$ for $2 \mathrm{~min}, 42$ cycles of $94^{\circ} \mathrm{C}$ for $45 \mathrm{~s}$, $60^{\circ} \mathrm{C}$ for $45 \mathrm{~s}$ and $72^{\circ} \mathrm{C}$ for $1 \mathrm{~min}$, and a final extension at $72^{\circ} \mathrm{C}$ for $10 \mathrm{~min}$. Products were electrophoresed on an ABI 3130 automated DNA sequencer. Alleles were sized using the LIZ500 Size Standard (Applied Biosystems) and read using GeneMapper 4.0 software (Applied Biosystems).

The combined non-exclusion probability for the five loci set was estimated by the program Cervus 3.0.7 (Kalinowski et al., 2007). Parentage analyses for each of the 14 spawning events were performed by probabilistic and direct exclusion approaches using Cervus 3.0.7 (Kalinowski et al., 2007) and Vitassign (Vandeputte et al., 2006), respectively, to estimate the number of contributing males and females. Those cases, in which the parentage assignment by Cervus and Vitassign coincided. Still, there were some loci showing mismatches; they were treated as putative mutations either by the change in the number of repeats or by null alleles. The mutation rate per locus was calculated, dividing the number of mutations by twice the number of genotypes in the progeny at each locus. The mutation rate was also calculated for males and females.

\section{RESULTS}

The 18 microsatellite loci showed reliable genotyping patterns in the Lutjanus guttatus broodstock, resulting in high genetic diversity $\left(n_{a}=13.4 \pm 1.3 ; \mathrm{Ho}=0.88 \pm\right.$
0.05; Table 1). Three loci departed from HWE (only one after the Bonferroni correction) (Table 1), which can be explained by the potential presence of null alleles, rather than by stuttering or allele drop-out, as indicated by the Micro-Checker analysis. Fourteen loci are available to assess population genetic structure in wild L. guttatus (N. Diaz-Viloria, unpublish. data), and several loci are potentially useful for the other snapper species (Table 1).

For parentage assignment, 413 embryonated eggs were used. The combination of direct and probabilistic (95\% CL) exclusion methods resulted in $95.6 \%$ of the progeny $(n=395)$ assigned to a single parental couple, leaving $4.3 \%$ unassigned. Seventeen families (out of 24) were represented in the progeny (Table 2 ).

The reproductive season within the breeding tank spanned from June to November, with a peak number of spawns occurring in October. Most males (7A62-M, 1170-M, 1538-M and 2924-M) reproduced throughout the season and during consecutive days (Fig. 1a). In contrast, most of the progeny $(\mathrm{n}=384 ; 97.2 \%)$ were produced by only two of the four females (4B67-H and 4953-H), and spawning did not occur on consecutive days (Fig. 1b), indicating that females (at least 4B67H) spawn every other day.

Unexpected genotypes were observed in several families, resulting in a deviation from the expected Mendelian proportions (Table 3). As it is unlikely that these genotypes come from genotyping errors (the sequencer sizing differences observed in four duplicated samples was between 0-0.7 units in at least four loci), they appear to be a consequence of both null and mutated alleles. Considering a null allele as a mutation event, the mutation rate per locus varied between a maximum of $1.2 \times 10^{-1}$ in $\operatorname{Lgut} 21$ to a minimum of $7.7 \times 10^{-3}$ in Lgut 34 , for a mean of $4.5 \times 10^{-2}$. Null-allele events were three times larger than changes in the number of repeats. While all the mutations in Lgut 21 and Lgut 39 were due to null alleles, there was a combination of null alleles and base pairs gains in the other loci (Table 3). In Lgut18 and Lgut30, the most common change was a gain in four base pairs (equivalent to one microsatellite repeat). The mutation rates were, on average, almost twice higher for females than males (Table 4).

\section{DISCUSSION}

The usefulness of microsatellites as genetic markers for parentage assignment has been demonstrated in more than 20 cultivated fish species (Yue \& Xia, 2014). The capability of correct assignment is dependent on several characteristics of the genetic markers, of which their 
Table 2. The number of progenies assigned to each potential family in the spawning events of July to October, using the probabilistic (95\% confidence level) and direct exclusion methods.

\begin{tabular}{cccccc}
\hline Female & Male & $\begin{array}{c}\text { Number of } \\
\text { individuals }\end{array}$ & Female & Male & $\begin{array}{c}\text { Number of } \\
\text { individuals }\end{array}$ \\
\hline \multirow{5}{*}{ 4953_H } & 1170_M & 54 & & 1170_M & 61 \\
& 1538_M & 8 & & 1538_M & 46 \\
& 2924_M & 39 & 4B67_H & 2924_M & 30 \\
& 6720_M & 14 & & 6720_M & 8 \\
& 7A62_M & 54 & & 7A62_M & 53 \\
& 3C42_M & 2 & 3C42_M & 15 \\
\hline \multirow{5}{*}{ 2C30_H } & 1170_M & 0 & & 1170_M & 0 \\
& 1538_M & 1 & & $1538 \_M$ & 0 \\
& 2924_M & 4 & IF70_H & 2924_M & 1 \\
& 6720_M & 0 & & 6720_M & 0 \\
& 7A62_M & 3 & 7A62_M & 0 \\
& 3C42_M & 2 & & 3C42_M & 0 \\
\hline \multicolumn{5}{r}{ Total number of families with progeny } & 17 \\
\hline
\end{tabular}
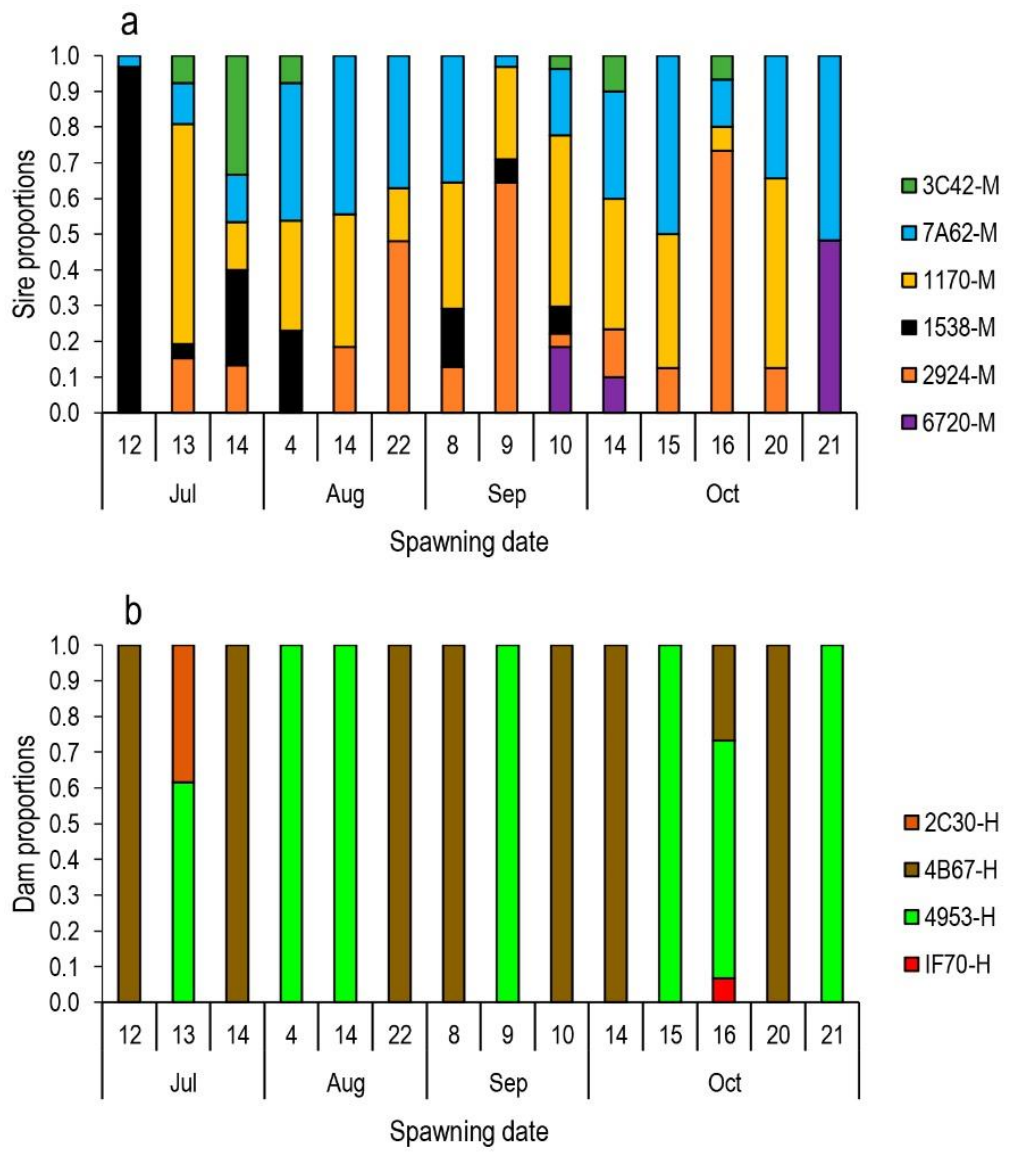

Figure 1. The proportion of breeders contributing to progeny during the spawning events of July-October 2011. a) Males, b) females.

variability is one of the most relevant (Vandeputte \& Haffray, 2014). The five high-variable microsatellites selected (with a combined probability of non-exclusion in the order of $10^{-6}$ ) were enough to confidently determine, by both exclusion methods, the parentage of 92\% of the progeny from a relatively small Lutjanus 


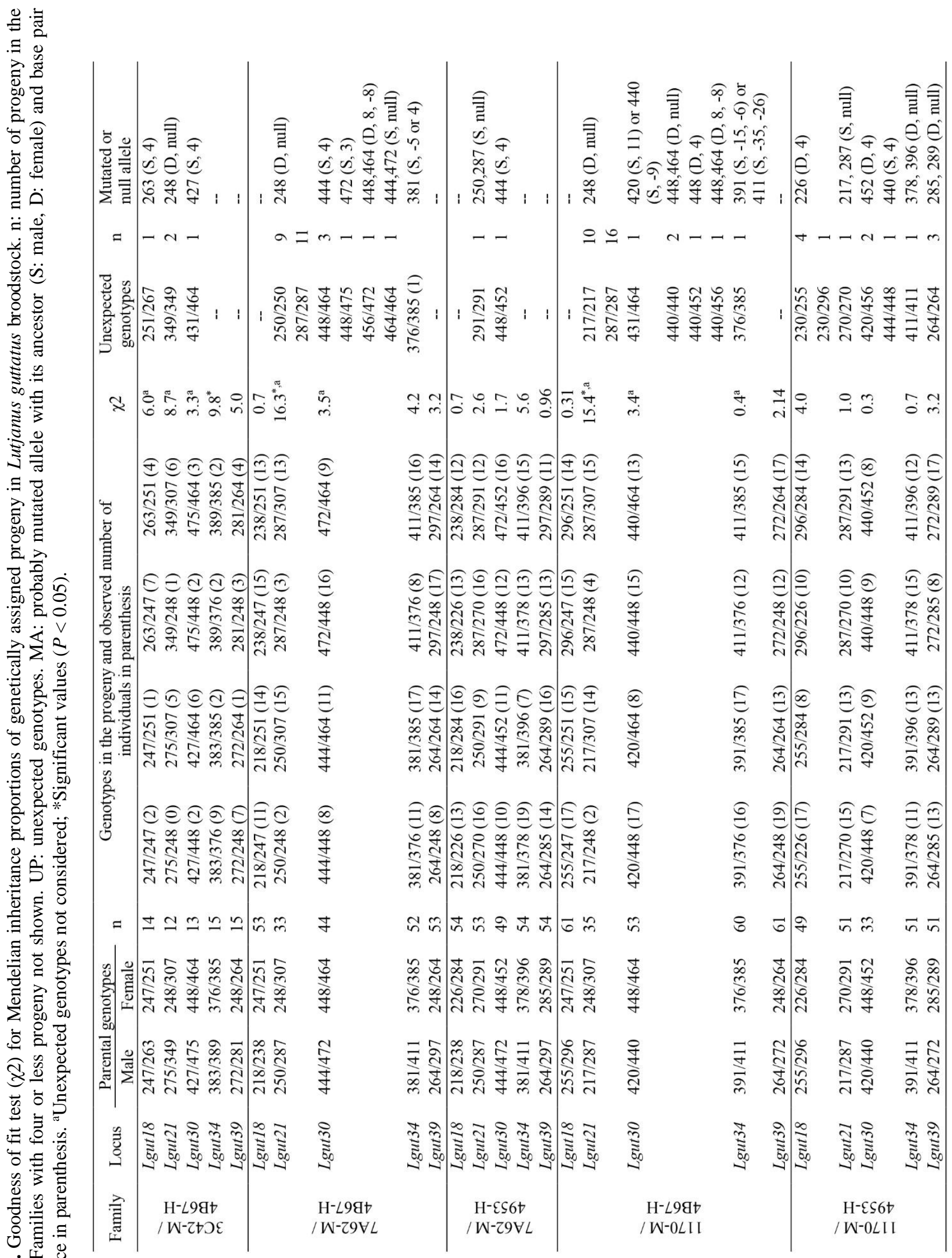




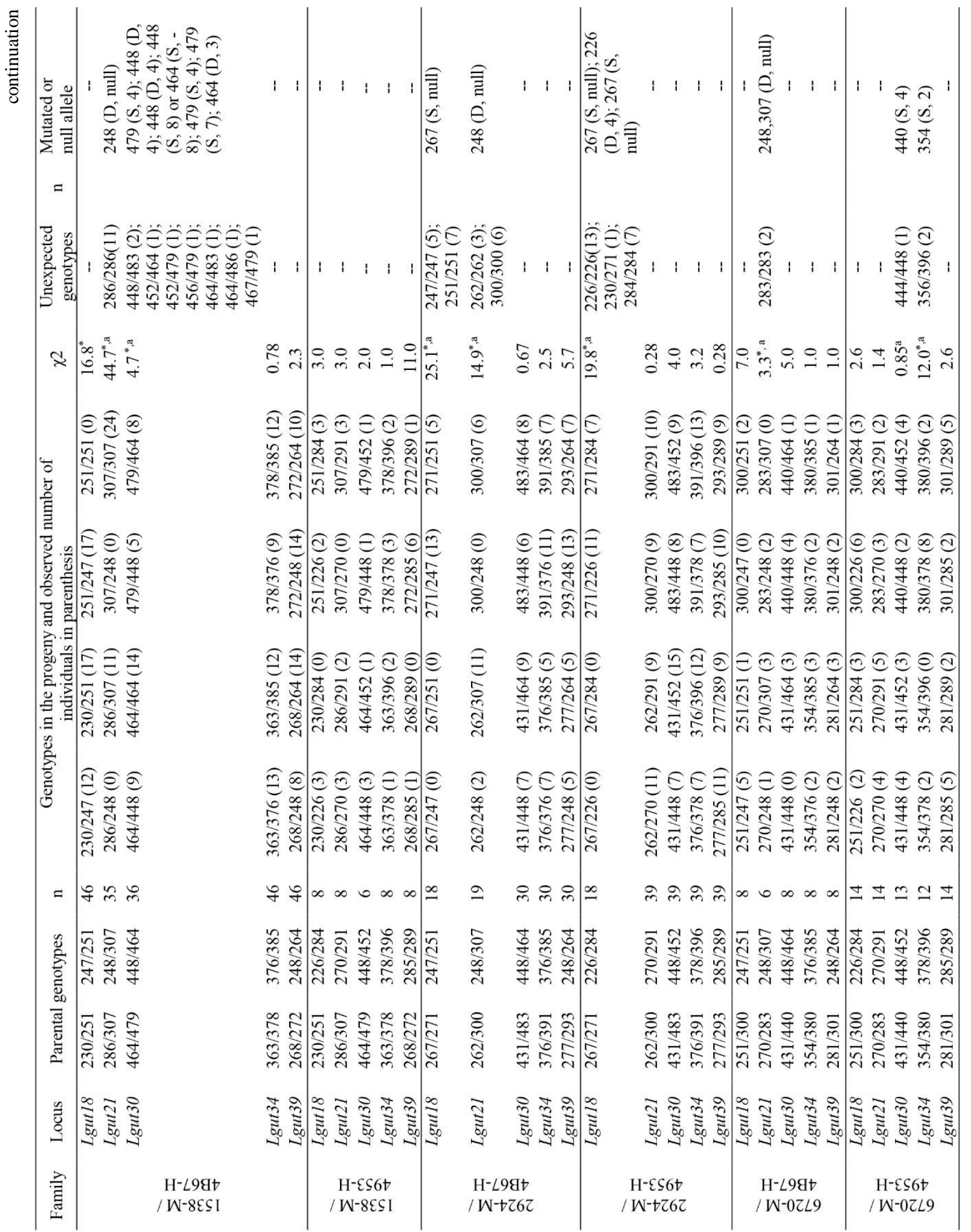


Table 4. Number of genotypes per parent (progeny per parent $\times 5$ loci), non-scored genotypes from progeny, number of mutated and null alleles, and estimated mutation rate.

\begin{tabular}{lcccccc}
\hline Parent & ID & $\begin{array}{c}\text { Genotypes } \\
\text { per parent }\end{array}$ & $\begin{array}{c}\text { Non-scored } \\
\text { progeny genotypes }\end{array}$ & Mutations & Null & $\begin{array}{c}\text { Mutation rate } \\
\left(\times 10^{-2}\right)\end{array}$ \\
\hline Male & 3 C42-M & 95 & 3 & 2 & 0 & 2.2 \\
& 7A62-M & 550 & 7 & 6 & 2 & 1.5 \\
& $1170-\mathrm{M}$ & 590 & 31 & 3 & 2 & 0.9 \\
& $1538-\mathrm{M}$ & 275 & 2 & 5 & 0 & 1.8 \\
& $2924-\mathrm{M}$ & 370 & 2 & 0 & 34 & 9.2 \\
& $6720-\mathrm{M}$ & 110 & 0 & 3 & 0 & 2.7 \\
& Mean & 331.7 & 7.5 & 3.2 & 6.3 & 3.1 \\
Female & $2 \mathrm{C} 30-\mathrm{H}$ & 50 & 0 & 1 & 6 & 14 \\
& $4 \mathrm{~B} 67-\mathrm{H}$ & 1080 & 15 & 6 & 74 & 7.5 \\
& $4953-\mathrm{H}$ & 855 & 28 & 6 & 4 & 1.2 \\
& IF70-H & 5 & 2 & 0 & 0 & 0 \\
& Mean & 497.5 & 11.3 & 3.3 & 21 & 5.7 \\
\hline
\end{tabular}

guttatus broodstock, supporting the usefulness of this reduced panel, for the assessment of multiple spawning events. The use of new genetic markers, such as SNPs, is an alternative for parentage testing in relevant aquaculture such as shrimp (Perez-Enriquez \& MaxAguilar, 2016), and oysters (Lapègue et al., 2014). Routine genotyping platforms are available; however, these types of platforms are not yet available for $L$. guttatus. Other techniques (e.g., KASP, Taqman, HRM) are not economically feasible for more than 50 SNPs.

The reproductive pattern of males, most of them reproducing throughout the season and during consecutive days, has also been observed in the California yellowtail Seriola lalandi Valenciennes, 1833 (Smith et al., 2015). In wild L. guttatus females, asynchronous development of the gonads and partial spawning behavior has been described (ArellanoMartínez et al., 2001). The overrepresentation of females should be taken into account for hatchery management as an unbalanced family size that can lead to an increased inbreeding rate (Perez-Enriquez et al., 1999; García-Fernández et al., 2018).

Parentage assessment within a day of a spawning event by using the DNA extracted from fish embryonated eggs is recommended using a mechanical method rather than a chemical method as in other fish species [e.g., gilthead seabream Sparus aurata (GarcíaFernández et al., 2018); zebrafish Danio rerio (Westerfield, 2007)]. However, the selection of embryonated eggs posterior to gastrula for DNA analysis is critical for PCR success, as similar results were reported for the gilthead seabream (García-Fernández et al., 2018).
Mutations and null alleles in microsatellites are a common phenomenon resulting in failed assignments (Ellegren, 2000). The mean mutation rate obtained in our study $\left(10^{-2}\right.$ per locus per generation) is higher than other fish species, such as the carp Cyprinus carpio with $10^{-4}$ (Yue et al., 2007), or various salmonids with $10^{-2}-10^{-5}$ (Shaikhaev \& Zhivotovsky, 2014). Despite the high mutation rate, five high-variable microsatellites were enough to confidently determine, by direct exclusion, the parentage of progeny from a relatively small broodstock of the spotted rose snapper. For a larger broodstock, the number of genetic markers can be increased to minimize the non-exclusion probability (in the order of magnitude of $10^{-6}$ in the present study), using the remaining markers developed for the species (Table 1).

The estimation of the contribution of males and females of broodstocks kept in communal tanks is relevant for the implementation of selective breeding programs (García-Fernández et al., 2018). A more intensive and extended in time genotyping that gives a better genetic representation of the gene pool of the selected broodstock has been suggested for the red sea bream Pagrus major (Nugrohoa \& Taniguchi, 2004) and the barramundi Lates calcarifer (Domingos et al., 2014). This information will also be important for the definition of the breeding goal, not only if the plan is focused on the improvement of reproductive traits, but also for other characteristics (growth, stress resistance, meat quality, others) (Gjedrem, 2012).

As an additional contribution, the genetic markers panel will also be useful for genetic studies in wild populations focused on their management in other lutjanid species. 


\section{ACKNOWLEDGMENTS}

This work was partially supported by CONACYT, Mexico [grant number CB-2015-1-257019 to NDV]. S. Avila provided technical support for the genetic analysis. Thanks to R. Peña, R. Martínez Moreno, I. Miguel Hernández, and I. Zavala Leal for spawn collections. S. Dumas is a COFAA-IPN and EDI-IPN fellow. N. Diaz-Viloria is an EDI-IPN fellow.

\section{REFERENCES}

Aljanabi, S.M. \& Martinez, I. 1997. Universal and rapid salt-extraction of high-quality genomic DNA for PCRbased techniques. Nucleic Acids Research, 25: 46924693.

Arellano-Martínez, M., Rojas-Herrera, A., GarcíaDomínguez, F., Ceballos-Vázquez, B.P. \& VillalejoFuerte, M. 2001. Reproductive cycle of the spotted rose snapper Lutjanus guttatus (Steindachner, 1869) in the Guerrero coast, Mexico. Revista de Biología Marina y Oceanografía, 36: 1-8.

Blonk, R.J.W., Komen, J., Kamstra, A., Crooijmans, R.P.M.A. \& Van Arendonk, J.A.M. 2009. Levels of inbreeding in group mating captive broodstock populations of common sole, (Solea solea) inferred from parental relatedness and contribution. Aquaculture, 289: 26-31. doi: 10.1016/j.aquaculture.2009.01. 012

Correa-Herrera, T. \& Jiménez-Segura, L.F. 2013. Biología reproductiva de Lutjanus guttatus (Perciformes: Lutjanidae) en el Parque Nacional Natural Utría, Pacífico Colombiano. Revista de Biología Tropical, 61: 829-840.

Domingos, J.A., Smith-Keune, C. \& Jerry, D.R. 2014. Fate of genetic diversity within and between generations and implications for DNA parentage analysis in selective breeding of mass spawners: A case study of commercially farmed barramundi, Lates calcarifer. Aquaculture, 424-425: 174-182.

Ellegren, H. 2000. Microsatellite mutations in the germline: implications for evolutionary inference. Trends in Genetics, 16: 551-558.

Excoffier, L. \& Lischer, H.E.L. 2010. Arlequin suite ver 3.5: a new series of programs to perform population genetics analyses under Linux and Windows. Molecular Ecology Resources, 10: 564-567.

Fischer, W., Krupp, F., Schneider, W., Sommer, C., Carpenter, K. \& Niem, V. 1995. Guía FAO para la identificación de especies del Pacífico centro-oriental. Vertebrados. FAO, Rome.
García-Fernández, C., Sánchez, J.A. \& Blanco, G. 2018. Early assessment of gilthead sea bream (Sparus aurata) spawning dynamics by mini-broodstocks. Aquaculture Research, 49: 36-47.

Gjedrem, T. 2012. Selection and breeding programs in aquaculture. Springer, Berlin.

Hallerman, E.M. 2003. Population genetics: principles and applications for fisheries scientists. American Fisheries Society, Bethesda.

Herrera-Ulloa, A., Chacón-Guzmán, J., Zúñiga-Calero, G. \& Jiménez-Montealegre, R. 2010. Spotted rose snapper (Lutjanus guttatus) aquaculture research and development as a socio-economic alternative for Costa Rican fishing communities. Journal of the World Aquaculture Society, 41(2): 20-22.

Ibarra-Castro, L., Martínez-Cordero, F.J. \& ÁlvarezLajonchère, L. 2013. Financial analysis of pilot-scale egg production of spotted rose snapper, Lutjanus guttatus. Aquaculture Economics \& Management, 17: 171-183.

Kalinowski, S.T., Taper, M.L. \& Marshall, T.C. 2007. Revising how the computer program CERVUS accommodates genotyping error increases success in paternity assignment. Molecular Ecology, 16(5): 1099-1106.

Lapègue, S., Harrang, E., Heurtebise S., Flahauw, E., Donnadieu, C., Gayral, P. et al. 2014. Development of SNP genotyping arrays in two shellfish species. Molecular Ecology Resources, 14: 820-830.

Nugrohoa, E. \& Taniguchi, N. 2004. Daily change of genetic variability in hatchery offspring of red sea bream during spawning season. Fisheries Science, 70: 638-644.

Perez-Enriquez, R. \& Max-Aguilar, A. 2016. Pedigree traceability in whiteleg shrimp (Litopenaeus vannamei) using genetic markers: a comparison between microsatellites and SNPs. Ciencias Marinas, 42: 227235.

Perez-Enriquez, R., Takagi, M. \& Taniguchi, N. 1999. Genetic variability and pedigree tracing of a hatcheryreared stock of red sea bream (Pagrus major) used for stock enhancement, based on microsatellite DNA markers. Aquaculture, 173: 411-421.

Sarabia-Méndez, M., Gallardo-Cabello, M., Espino-Barr, E. \& Anislado-Tolentino, V. 2010. Characteristics of population dynamics of Lutjanus guttatus (Pisces: Lutjanidae) in Bufadero Bay, Michoacán, Mexico. Hidrobiologica, 20: 147-157.

Schuelke, M. 2000. An economic method for the fluorescent labeling of PCR fragments. Nature Biotechnology, 18: 233-234.

Shaikhaev, E.G. \& Zhivotovsky, L.A. 2014. The evolution of microsatellite loci in salmonid fishes. Russian Journal of Genetics, 50: 853-859. 
Smith, E.K., Drawbrige, M. (MS), Hyde, J. (PhD) \& Geoffrey, M. (PhD). 2015. Evaluation of reproductive strategies in California yellowtail (Seriola dorsalis) using genetic parentage analyses. Thesis, 6. doi: $10.22371 / 02.2015 .021$

Vandeputte, M. \& Haffray, P. 2014. Parentage assignment with genomic markers: a major advance for understanding and exploiting genetic variation of quantitative traits in farmed aquatic animals. Frontiers in Genetics, 5: 432.

Vandeputte, M., Mauger, S. \& Dupont-Nivet, M. 2006. An evaluation of allowing for mismatches as a way to manage genotyping errors in parentage assignment by exclusion. Molecular Ecology Resources, 6: 265-267.
Van-Oosterhout, C., Hutchinson, W.F., Wills, D.P.M. \& Shipley, P. 2004. Micro-Checker: software for identifying and correcting genotyping errors in microsatellite data. Molecular Ecology Notes, 4: 535538.

Westerfield, M. 2007. The zebrafish book. A guide for the laboratory use of zebrafish (Danio rerio). University of Oregon Press, Eugene.

Yue, G.H. \& Xia, J.H. 2014. Practical considerations of molecular parentage analysis in fish. Journal of the World Aquaculture Society, 42: 89-103.

Yue, G.H., David, L. \& Orban, L. 2007. Mutation rate and pattern of microsatellites in common carp (Cyprinus carpio L.). Genetica, 129: 329-331.

Received: 27 August 2019; Accepted: 21 November 2019 